\title{
Co-development of diagnostic vectors to support targeted therapies and theranostics: essential tools in personalized cancer therapy
}

\section{Nicholas C. Nicolaides, Daniel J. O'Shannessy *, Earl Albone and Luigi Grasso}

Department of Translational Medicine and Diagnostics, Morphotek Inc., Exton, PA, USA

\section{Edited by:}

Jan Trøst Jørgensen, Dx-Rx Institute,

Denmark

\section{Reviewed by:}

Hu Liu, Anhui Medical University, China

Alex Zhavoronkov, Federal Research

Clinical Center for Pediatric

Hematology, Oncology and

Immunology, Russia

\section{*Correspondence:}

Daniel J. O'Shannessy, Department

of Translational Medicine and

Diagnostics, Morphotek Inc., 210

Welsh Pool Road, Exton, PA 19341,

USA

e-mail: doshannessy@

morphotek.com
Novel technologies are being developed to improve patient therapy through the identification of targets and surrogate molecular signatures that can help direct appropriate treatment regimens for efficacy and drug safety. This is particularly the case in oncology whereby patient tumor and biofluids are routinely isolated and analyzed for genetic, immunohistochemical, and/or soluble markers to determine if a predictive biomarker signature (i.e., mutated gene product, differentially expressed protein, altered cell surface antigen, etc.) exists as a means for selecting optimal treatment. These biomarkers may be drug-specific targets and/or differentially expressed nucleic acids, proteins, or cell lineage profiles that can directly affect the patient's disease tissue or immune response to a therapeutic regimen. Improvements in diagnostics that can prescreen predictive response biomarker profiles will continue to optimize the ability to enhance patient therapy via molecularly defined disease-specific treatment. Conversely, patients lacking predictive response biomarkers will no longer needlessly be exposed to drugs that are unlikely to provide clinical benefit, thereby enabling patients to pursue other therapeutic options and lowering overall healthcare costs by avoiding futile treatment. While patient molecular profiling offers a powerful tool to direct treatment options, the difficulty in identifying disease-specific targets or predictive biomarker signatures that stratify a significant fraction within a disease indication remains challenging. A goal for drug developers is to identify and implement new strategies that can rapidly enable the development of beneficial disease-specific therapies for broad patient-specific targeting without the need of tedious predictive biomarker discovery and validation efforts, currently a bottleneck for development timelines. Successful strategies may gain an advantage by employing repurposed, less-expensive existing agents while potentially improving the therapeutic activity of novel, target-specific therapies that may otherwise have off-target toxicities or less efficacy in cells exhibiting certain pathways. Here, we discuss the use of co-developing diagnostic-targeting vectors to identify patients whose malignant tissue can specifically uptake a targeted anti-cancer drug vector prior to treatment. Using this system, a patient can be predetermined in real-time as to whether or not their tumor(s) can specifically uptake a drug-linked diagnostic vector, thus inferring the uptake of a similar vector linked to an anti-cancer agent. If tumor-specific uptake is observed, then the patient may be suitable for drug-linked vector therapy and have a higher likelihood of clinical benefit while patients with no tumor uptake should consider other therapeutic options. This approach offers complementary opportunities to rapidly develop broad tumor-specific agents for use in personalized medicine.

Keywords: companion diagnostics, CDx, co-development, TM601, theranostics, nanoparticles, naturally occurring proteins, personalized medicine

\section{PERSONALIZED MEDICINE IN THE ERA OF TARGETED THERAPEUTIC STRATEGIES}

Personalized medicine is generally considered as the precise use of drug(s) that can specifically target a patient's diseased tissue. This is typically achieved by using a diagnostic biomarker or biomolecular signature that can predict clinical response in patients before they are treated (1). In the broadest sense, an example of personalized medicine can be found in the therapeutic management of type 1 diabetes. Patients with this condition are identified initially by abnormal blood glucose levels, whereby glucose serves as a biomarker. Once confirmed by follow-up testing, the disease can be managed by drugs capable of modulating active insulin levels.

In more complex diseases such as cancer, an array of genetic and altered gene product expression changes may be required to determine or predict a patient's specific response(s) to therapy. Anti-cancer therapeutic strategies include: (i) binding to a specific 
molecular target of an altered pathway or a sequence-specific gene product that in turn results in selective killing of malignant but not normal cells; (ii) inducing a host immune response against malignant cells; and (iii) enhancing specific uptake of an agent(s) in target cells for disease suppression. Based on their chemical or biochemical nature, targeted anti-cancer agents can be classified into small chemical entities (SCE) capable of disrupting cellular processes such as enzymatic reactions, tubulin polymerization and DNA replication; nucleic acids that can specifically bind a gene product involved in tumor growth and metastasis; and cellular- and protein-based therapies that can specifically target tumor-associated cell surface proteins or soluble ligands (2). All these agents exert their pharmacologic activity by specifically suppressing growth and survival in malignant vs. normal cells.

For targeted cancer therapies, it is important that the compound can specifically bind to a gene product (e.g., ligands/receptors, transcription factors, or enzymes) or a molecular target within a pathway unique to a tumor cell or cells located within the tumor microenvironment that support tumor growth. These agents may include cell and protein-based vaccines, peptides, recombinant proteins, antibodies, antibody fragments, nucleic acid, and target-specific SCEs (2). The development of novel SCEs targeting tumor-altered gene products involved in driving the underlying cause of transformation is expanding across the industry as a result of recent approvals of compounds in this class (3). These include the anti BCR-ABL fusion protein tyrosine kinase inhibitor imatinib (4) and the more recently approved translocated ALK inhibitor, crizotinib (5), and mutant BRAF inhibitor, vemurafenib (6). While this class has shown robust clinical activity in patients containing the altered gene product, the low target frequency of the latter two compounds has minimized their utility in the greater patient population. Other classes of targeted therapies include antibody and protein-based agents that can specifically bind cell surface proteins on tumor cells and in turn block or activate receptor signaling, induce programed cell death and/or induce immune-mediated cytotoxicity. In all cases, patients may be prescreened to determine if their tumor expresses an agentspecific molecular target. These examples provide support for the validity of discovering modified disease-specific gene products that can serve as drug targets and be used to prescreen patients via diagnostic platforms capable of identifying those eligible for target-specific therapy.

Other personalized platforms include those that monitor gene expression profiles or soluble markers contained within biofluids (serum, plasma, urine, sputum, or whole cells) that may serve as surrogates for predictive response to a therapeutic regimen. While the example of type 1 diabetes fits into this category, broader discovery approaches are being pursued in oncology. These include biomarker signature profiles within disease tissue that may predict response to certain chemotherapeutic regimens as well as modifier genes that may predict response to a targeted therapy (7). The use of tumor-specific biomarker signature profiles has been widely pursued in breast cancer based on early successful prognostic and therapeutic paradigms that relied on tumor stage and grade, as well as HER2, estrogen (ER), and progesterone (PR) receptor expression status. Subsequent efforts have further refined breast cancer marker profiling to guide best course of therapy
(8). This was achieved by development of a molecular signature panel comprising 21 genes, called Oncotype DX ${ }^{\circledR}$ (9), and subsequently MammaPrint ${ }^{\mathrm{TM}}(10)$, which comprises a 70 gene set. In both cases, surrogate gene expression profiles are measured to predict a patient's prognosis and guidance for use of existing therapies. More recently, a similar product for patient prognosis in colorectal cancer (OncoDX) has been developed (11). While these molecular signatures have value in predicting an individual's prognosis, they cannot predict potential clinical responses after specific targeted therapy. Despite their success and widespread use in breast or colorectal cancer for clinical follow-up after initial diagnosis, the generation and validation of these gene product signatures has taken a significant amount of time and effort before achieving clinical utility in managing personalized treatment for cancer patients.

There are currently 19 FDA approved companion diagnostic $(\mathrm{CDx})$ assays, 18 of which are approved in oncology (Table 1). Ten of the $18 \mathrm{CDx}$ assays are various qualitative assays for detecting HER2 expression or amplification in breast cancer; 2 are qualitative assays for BRAF V600E mutations; along with qualitative assays for ALK translocations, KRAS mutations and c-KIT; and 3 qualitative assays for EGFR mutations. The relative paucity of FDA approved CDx assays might reflect the difficulty and complexity in requirements for approval of such assays but might also be a reflection of a lack of in-depth knowledge of the underlying biology of cancer and/or the drug target interaction. Further, it is interesting to note that only 3 of the $18(17 \%)$ oncology CDx assays are quantitative in format. While quantitative assays are not necessarily required, this undoubtedly speaks to the differences in regulatory requirements for quantitative relative to qualitative assays, at least with respect to CDx assays.

Interestingly, many more molecular diagnostic (Dx) assays are in drug labels (Table 2) - not as companion diagnostics but recommended or even required prior to prescribing therapy or for therapeutic monitoring - and some of these have been cleared by the FDA through the $510(\mathrm{k})$ process (Table 3$)$. Complex pharmacogenomics signatures such as Oncotype DX ${ }^{\circledR}$ and even BRCA mutation analyses (12) are routinely used in clinical oncology but are performed under the CLIA regulation (Clinical Laboratory Improvement Amendments of 1988) and are classified as Laboratory Developed Tests (LDTs). This class of Dx does not go through the rigor of regulatory submissions such as $510(\mathrm{k})$ or PMA (PreMarket Approval; a CDx requires a PMA) nor the post-marketing requirements of such assays. The FDA is currently reviewing and is expected to make recommendations in the near future regarding the oversight of LDTs, which may (significantly) change the present landscape.

\section{ANTIBODY-DRUG CONJUGATES AND RADIOIMMUNOTHERAPIES}

Recent clinical success of monoclonal antibody (mAb) drug conjugates (ADCs) has spurred the field of highly toxic chemotherapeutic drugs for targeted therapy. The development of ADCs offers dual benefits: the ability to preselect patients whose disease expresses the target antigen for tumor-specific delivery and the opportunity to deliver highly toxic (novel or repurposed) compounds to antigen positive tumors while avoiding toxic off-target effects commonly found with non-targeted SCEs or radionuclides 
Table 1 | FDA approved companion diagnostics (CDx)

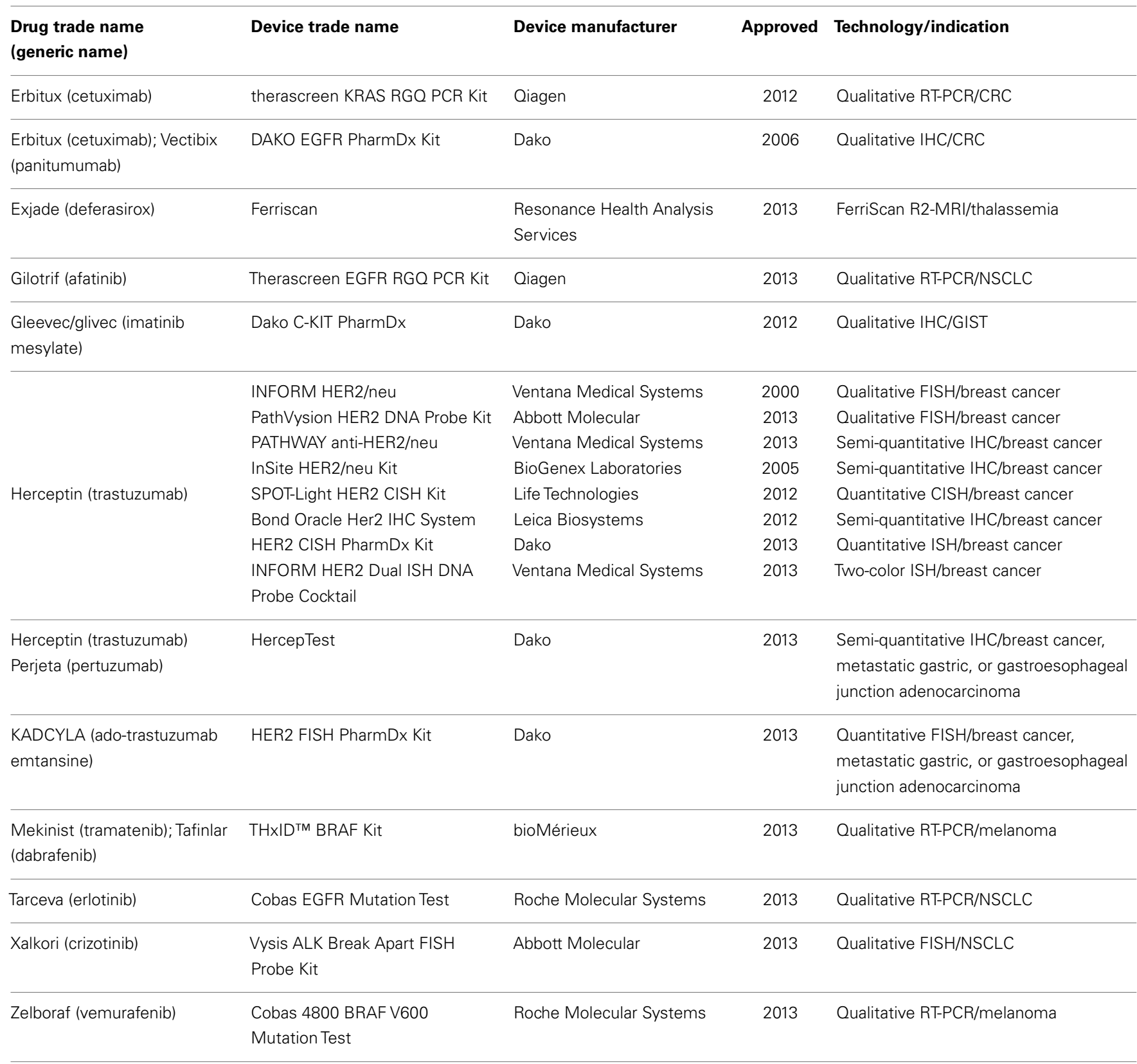

Source: http://www.fda.gov/MedicalDevices/ProductsandMedicalProcedures/InVitroDiagnostics/ucm301431.htm.

(hereon referred to as cytotoxins) (13). Enhanced technologies that enable robust linkage of a targeting agent to a cytotoxin such as radionuclides, chemotherapeutic SCEs, and gene silencing nucleic acids has led to the establishment of a wide array of next generation targeted therapies (14). The targeting moieties themselves have varied from full-length antibodies to recombinant proteins, small polypeptides, and nanoparticles (NPs). A diversity of linkage chemistries that allow conjugation of a cytotoxin to the targeting agent have been implemented depending upon where in the tissue it is most desirable to have the cytotoxin delivered and, if required, liberated from the targeting agent. With the early success of antibody-cytotoxin conjugates using radionuclides (referred to as radioimmunotherapy, RIT), such as yttrium-90 $\left({ }^{90} \mathrm{Y}\right)$-labeled-ibritumomab tiuxetan (15) and iodine-131 ( ${ }^{131} \mathrm{I}$ )-labeled tositumomab (16) in treating refractory lymphoma, as well as the recently approved ADC trastuzumabDM1 (T-DM1, Kadcyla ${ }^{\circledR}$ ) (17), and brentuximab vedotin (SGN35, Adcetris $\left.^{\circledR}\right)(18)$, significant progress in personalized medicine has been attained (19). Part of this advancement is due to the improved therapeutic activity over the parental agents (the cytotoxic or targeting agent alone) resulting in a better clinical outcome while minimizing toxicity. Rituximab is a chimeric mouse-human IgG1 $\mathrm{mAb}$ directed to the $\mathrm{CD} 20$ cell surface protein and approved for treatment of B-cell lymphomas. ${ }^{90}$ Y-labeled-ibritumomab 
Table 2 | Molecular diagnostics (Dx) in US drug labels.

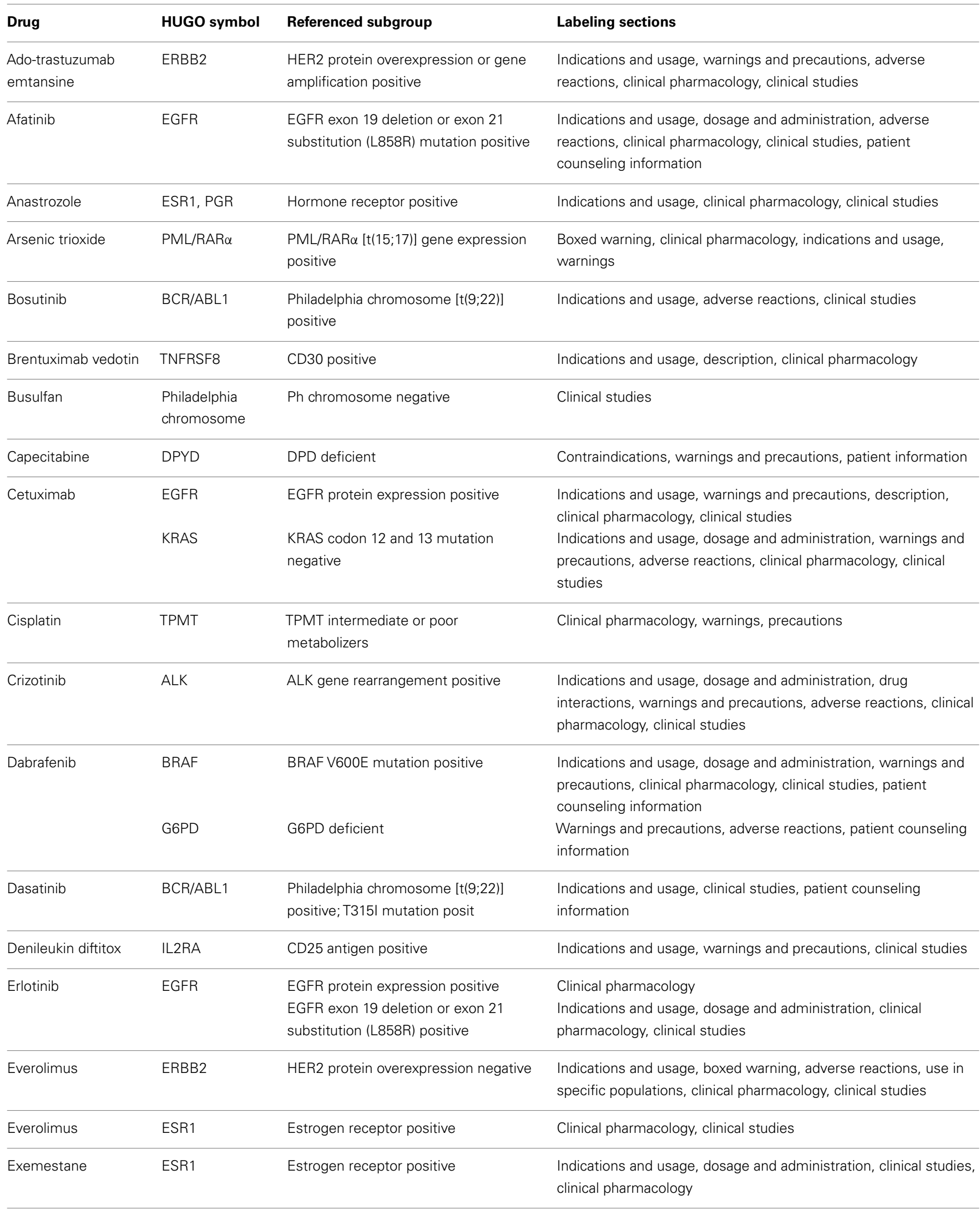




\section{Table 2 | Continued}

\begin{tabular}{|c|c|c|c|}
\hline Drug & HUGO symbol & Referenced subgroup & Labeling sections \\
\hline Fluorouracil & DPYD & DPD deficient & Warnings \\
\hline Fulvestrant & ESR1 & Estrogen receptor positive & $\begin{array}{l}\text { Indications and usage, clinical pharmacology, clinical studies, } \\
\text { patient counseling information }\end{array}$ \\
\hline $\begin{array}{l}\text { Ibritumomab } \\
\text { tiuxetan }\end{array}$ & MS4A1 & CD20 positive & Indications and usage, clinical pharmacology, description \\
\hline \multirow[t]{4}{*}{ Imatinib } & $\mathrm{KIT}$ & c-KIT D816V mutation negative & Indications and usage, dosage and administration clinical \\
\hline & $\mathrm{BCR} / \mathrm{ABL} 1$ & $\begin{array}{l}\text { Philadelphia chromosome }[t(9 ; 22)] \\
\text { positive }\end{array}$ & pharmacology, clinical studies \\
\hline & PDGFR $\beta$ & PDGFR gene rearrangement positive & \\
\hline & FIP1L1/PDGFR $\alpha$ & $\begin{array}{l}\text { FIP1L1/PDGFR } \alpha \text { fusion kinase (or } \\
\text { CHIC2 deletion) positive }\end{array}$ & Indications and usage, dosage and administration, clinical studies \\
\hline Irinotecan & UGT1A1 & UGT1A $1 * 28$ allele carriers & Dosage and administration, warnings, clinical pharmacology \\
\hline Lapatinib & ERBB2 & HER2 protein overexpression positive & $\begin{array}{l}\text { Indications and usage, clinical pharmacology, patient counseling } \\
\text { information }\end{array}$ \\
\hline Letrozole & ESR1, PGR & Hormone receptor positive & $\begin{array}{l}\text { Indications and usage, adverse reactions, clinical studies, clinical } \\
\text { pharmacology }\end{array}$ \\
\hline Mercaptopurine & TPMT & $\begin{array}{l}\text { TPMT intermediate or poor } \\
\text { metabolizers }\end{array}$ & $\begin{array}{l}\text { Dosage and administration, contraindications, precautions, } \\
\text { adverse reactions, clinical pharmacology }\end{array}$ \\
\hline Nilotinib & $\mathrm{BCR} / \mathrm{ABL} 1$ & $\begin{array}{l}\text { Philadelphia chromosome }[t(9 ; 22)] \\
\text { positive }\end{array}$ & Indications and usage, patient counseling information \\
\hline Nilotinib & UGT1A1 & UGT1A $1 * 28$ allele homozygotes & Warnings and precautions, clinical pharmacology \\
\hline Ofatumumab & MS4A1 & CD20 positive & Indications and usage, clinical pharmacology \\
\hline Omacetaxine & BCR/ABL1 & BCR-ABLT315I & Clinical pharmacology \\
\hline \multirow[t]{2}{*}{ Panitumumab } & EGFR & EGFR protein expression positive & $\begin{array}{l}\text { Indications and usage, warnings and precautions, clinical } \\
\text { pharmacology, clinical studies }\end{array}$ \\
\hline & KRAS & $\begin{array}{l}\text { KRAS codon } 12 \text { and } 13 \text { mutation } \\
\text { negative }\end{array}$ & Indications and usage, clinical pharmacology, clinical studies \\
\hline Pazopanib & UGT1A1 & $\begin{array}{l}(\mathrm{TA}) 7 /(\mathrm{TA}) 7 \text { genotype } \\
\left(\mathrm{UGT} 1 \mathrm{~A} 1{ }^{*} 28 /{ }^{*} 28\right)\end{array}$ & Clinical pharmacology, warnings and precautions \\
\hline Pertuzumab & ERBB2 & HER2 protein overexpression positive & $\begin{array}{l}\text { Indications and usage, warnings and precautions, adverse } \\
\text { reactions, clinical studies, clinical pharmacology }\end{array}$ \\
\hline Ponatinib & BCR/ABL1 & $\begin{array}{l}\text { Philadelphia chromosome }[\mathrm{t}(9 ; 22)] \\
\text { positive, BCR-ABL T315I mutation }\end{array}$ & $\begin{array}{l}\text { Indications and usage, warnings and precautions, adverse } \\
\text { reactions, use in specific populations, clinical pharmacology, } \\
\text { clinical studies }\end{array}$ \\
\hline Rasburicase & G6PD & G6PD deficient & Boxed warning, contraindications \\
\hline Rituximab & MS4A1 & CD20 positive & $\begin{array}{l}\text { Indication and usage, clinical pharmacology, description, } \\
\text { precautions }\end{array}$ \\
\hline
\end{tabular}


Table 2 | Continued

\begin{tabular}{|c|c|c|c|}
\hline Drug & HUGO symbol & Referenced subgroup & Labeling sections \\
\hline \multirow[t]{3}{*}{ Tamoxifen } & ESR1, PGR & Hormone receptor positive & Indications and usage, precautions, medication guide \\
\hline & F5 & Factor $V$ Leiden carriers & Warnings \\
\hline & $\mathrm{F} 2$ & Prothrombin mutation G20210A & \\
\hline Thioguanine & TPMT & TPMT poor metabolizer & Dosage and administration, precautions, warnings \\
\hline Tositumomab & MS4A1 & CD20 antigen positive & Indications and usage, clinical pharmacology \\
\hline Trametinib & BRAF & BRAF V600E/K mutation positive & $\begin{array}{l}\text { Indications and usage, dosage and administration, adverse } \\
\text { reactions, clinical pharmacology, clinical studies, patient } \\
\text { counseling information }\end{array}$ \\
\hline Trastuzumab & ERBB2 & $\begin{array}{l}\text { HER2 protein overexpression } \\
\text { positive }\end{array}$ & $\begin{array}{l}\text { Indications and usage, warnings and precautions, clinical } \\
\text { pharmacology, clinical studies }\end{array}$ \\
\hline Tretinoin & PML/RARA & $\begin{array}{l}\mathrm{PML/RAR} \alpha[\mathrm{t}(15 ; 17)] \text { gene } \\
\text { expression positive }\end{array}$ & Clinical studies, indications and usage, warnings \\
\hline Vemurafenib & BRAF & BRAF V600E mutation positive & $\begin{array}{l}\text { Indications and usage, warning and precautions, clinical } \\
\text { pharmacology, clinical studies, patient counseling } \\
\text { information }\end{array}$ \\
\hline
\end{tabular}

Source: http://www.fda.gov/Drugs/ScienceResearch/ResearchAreas/Pharmacogenetics/ucm083378.htm

tiuxetan and $\mathrm{I}^{131}$-labeled tositumomab, both of which also target CD20, showed statistically significant clinical responses in patients as compared to rituximab or chemotherapy alone and were approved for use in rituximab-refractory patients. Unfortunately, the application of these RITs in clinical practice has been limited by the complexity of handling $\beta$-emitting radionuclidelabeled mAbs before and after patient treatment. These limitations have fostered the generation of alternate molecules, including alpha emitting RITs (20) as well as non-radioactive cytotoxins that can be more practically conjugated to $\mathrm{mAb}$, protein, or peptidebased targeting agents, without affecting their pharmacokinetic or pharmacodynamic properties (i.e., diminished ability to maximally and specifically access its target expressed by the diseased tissue). While therapeutic improvements have been reported in cancers using RITs and ADCs vs. non-conjugated agents, not all patients treated with RIT or ADC agents have shown enhanced benefit, suggesting diagnostic opportunities for improving the therapeutic use of conjugates (21). Table 4 provides an overview of approved ADCs and RITs.

As indicated above, continued improvement and development of targeted therapies, using ADCs, RITs, or other technologies, is required but not sufficient to realize the maximal therapeutic potential of personalized medicine. Tailoring of a therapy to an individual's cancer requires knowledge of the underlying biology of that cancer and may involve utilizing surrogate molecular signatures, drug target expression profiles, and/or degree of targeted conjugate uptake for predicting patient response. The heterogeneity described for individual tumors (22) only adds to the complexity of defining the biomolecular characteristics of a patient's malignant tissue and selecting a therapy, or combination of therapies, most likely to be effective for the individual patient.
In turn, such tumor heterogeneity adds to the complexity of development of the requisite surrogate Dx or CDx that is required to maximize the benefit of targeted therapies. It is generally accepted that the more complex the diagnostic platform, the more intricate is the regulatory path for approval, especially if the diagnostic is a CDx. A CDx is considered high risk by most regulatory authorities as it specifically dictates therapeutic intervention, in contrast to Oncotype Dx, MammaPrint, or OncoDX type diagnostic tools that merely supply information relative to prognosis and guide the therapeutic intervention. The development, analytical, and clinical validation of complex multi-marker diagnostic biomarker signatures is both time consuming and expensive. In addition, the alignment of therapeutic-diagnostic development timelines is challenging at best, especially if such signatures are not discovered until post hoc analysis of Phase 2 clinical trials. The recent clearance by the US FDA of next generation sequencing (NGS) instrumentation for cystic fibrosis is an important step for the use of new technologies to support complex assay developments, particularly as they relate to oncology where such complex signatures are likely required (23). However, as noted, biomarker signatures for predicting response to a given therapy may not simply involve gene expression or mutation profiles but, rather, complex gene product expression profiles.

\section{TARGETED CYTOTOXIC AGENTS - TCAs}

Despite the successful demonstration that targeted cytotoxic agents (TCAs), such as ADCs and RITs, can provide added clinical benefit for certain cancers, a number of challenges still remain for their clinical success across a broad spectrum of cancer indications. The effectiveness of targeted cytotoxin conjugates depends in part on the inherent features of the conjugate used. Some of the 
Table 3 | FDA 510(k) cleared molecular diagnostics (Dx)

\begin{tabular}{|c|c|c|c|c|}
\hline Disease state & Device & Year & Device manufacturer & Comments \\
\hline \multirow[t]{2}{*}{ AML } & Vysis EGR1 FISH & 2011 & Abbott Molecular & Deletions in EGR1; bone marrow specimens; aid in prognosis \\
\hline & Probe Kit & & & \\
\hline \multirow[t]{3}{*}{ B-cell CLL } & Vysis CLL FISH & 2011 & Vysis & Deletions in TP53, ATM, and D1I3S319 and gain in D1I2Z3; peripheral \\
\hline & Probe Kit & & & blood; aid in prognosis \\
\hline & CEP 12 DNA Probe & 1997 & Vysis & FISH; specific for centromere 12; peripheral blood; prognosis \\
\hline \multirow[t]{3}{*}{ Bladder cancer } & Vysis UroVysion & 2004 & Vysis & Aneuploidy of chromosomes 3, 7, 17 and loss of 9p21 locus; urine \\
\hline & Bladder Cancer & & & specimens; TCC; monitor recurrence \\
\hline & Recurrence Kit & & & \\
\hline \multirow[t]{6}{*}{ Breast cancer } & MammaPrint & 2011 & Agendia & $\begin{array}{l}\text { Gene expression profile; fresh frozen tissue; assess risk for distant } \\
\text { metastasis and prognosis }\end{array}$ \\
\hline & GeneSearch Breast & 2009 & Veridex & Gene expression panel; metastasis in lymph nodes; aids in the \\
\hline & Lymph Node (BLN) & & & decision to excise additional lymph nodes and staging \\
\hline & Test Kit & & & \\
\hline & Dako TOP2A FISH & 2012 & Dako & FISH to detect copy number changes of TOP2A; FFPE; prognosis in \\
\hline & PharmDx Kit & & & high risk breast cancer patients \\
\hline \multirow[t]{3}{*}{ Cystic fibrosis } & $\begin{array}{l}\text { eSensor CF } \\
\text { Genotyping Test }\end{array}$ & 2009 & $\begin{array}{l}\text { Osmetech Molecular } \\
\text { Diagnostics }\end{array}$ & $\begin{array}{l}\text { Detects a panel of mutations and variants in CFTR; genomic DNA; } \\
\text { genetic carrier screening }\end{array}$ \\
\hline & xTAG Cystic Fibrosis & 2009 & Luminex Molecular & Detects and identifies a panel of mutations and variants the CFTR; \\
\hline & 60 Kit v2 & & Diagnostics & genetic carrier and newborn screening \\
\hline \multirow[t]{4}{*}{ Prostate cancer } & NADiA ProsVue & 2011 & $\begin{array}{l}\text { Iris Molecular } \\
\text { Diagnostics }\end{array}$ & $\begin{array}{l}\text { Determines rate of change of total PSA; serum; an aid in identifying } \\
\text { those patients at reduced risk for recurrence of prostate cancer }\end{array}$ \\
\hline & PROGENSA PCA3 & 2012 & Gen-Probe & PCA3 and PSA RNA ratio; urine; aids physicians in determining the \\
\hline & Assay & & & need for repeat prostate biopsies in men who have had a previous \\
\hline & & & & negative biopsy \\
\hline \multirow[t]{4}{*}{ Tissue of origin } & Pathwork Tissue of & 2012 & Pathwork & Compares RNA expression patterns in a patient's FFPE tumor with \\
\hline & Origin Test Kit - FFPE & & Diagnostics & those in a database; tissue; aid in determining origin of cancer \\
\hline & Pathwork Tissue of & 2008 & Pathwork & Compares RNA expression patterns in a patient's fresh/frozen tumor \\
\hline & Origin Test & & Diagnostics & with those in a database; tissue; aid in determining origin of cancer \\
\hline
\end{tabular}

Source: http://www.fda.gov/MedicalDevices/ProductsandMedicalProcedures/InVitroDiagnostics/ucm330711.htm

TCA properties that can be optimized include: (1) tumor recognition and penetration; (2) serum half-life to minimize liberation of the cytotoxin in serum that may result in off-target effects; (3) targeting epitopes on a cell surface antigen that can support maximal conjugate internalization; (4) ability of the targeting agent to retain its target specificity in the conjugated form; and (5) large-scale conjugation of the cytotoxin to the targeting moiety for GMP manufacturing at a reasonable cost-of-goods. Smaller molecular weight targeting conjugates that employ antibody fragment or peptide platforms offer the opportunity to improve TCA tumor penetration (21), enhance binding specificities (24) and internalization (25), as well as lower serum half-lives to avoid prolonged circulation (26). Furthermore, smaller sized TCAs offer the ability to employ alternative manufacturing approaches to minimize cost-of-goods in contrast to mammalian cell fermentation that is required for manufacturing of full-length monoclonal antibodies. While antibody and antibody fragment conjugates appear to offer additional benefits for developing disease-specific therapies, the limited frequency in which a cell surface target is strictly expressed across heterogeneous disease vs. normal tissue remains a major drawback. In cancer, several cell surface targets have been identified that appear to be tumor-specific but the frequency of expression is quite variable from one tumor type to another thereby limiting the breadth by which an approved TCA can be used across different cancer indications (27). Furthermore, recent studies have demonstrated that the expression levels and/or distribution of cell surface targets on tumor cells or tumor-associated stromal cells can vary within the same specimen (28). Hence, the development of high affinity and high specificity targeting agents to maximize tumor recognition in cases of low and heterogeneous target expression is needed. The number of broadly expressed molecular targets that are present on a diseased cell and not on normal tissues that can be selectively targeted by a TCA is low. Nevertheless, several disease-specific antigens have been identified as a result of epigenetic mechanisms, alternative splicing, gene rearrangement, and overexpression that 
Table 4 | Examples of approved antibody-drug conjugates (ADCs) and radioimmunotherapeutics (RIT's) in oncology.

\begin{tabular}{|c|c|c|c|c|c|c|}
\hline $\begin{array}{l}\text { Trade name } \\
\text { (generic) }\end{array}$ & Manufacturer & Target & Conjugate & Approved & Indication & Comments \\
\hline \multicolumn{7}{|c|}{ ANTIBODY-DRUG CONJUGATES (ADCs) } \\
\hline \multicolumn{7}{|c|}{ Mylotarg } \\
\hline $\begin{array}{l}\text { Gemtuzumab } \\
\text { ozogamicin }\end{array}$ & Pfizer/Wyeth & CD33 & Calecheamicin & 2001 & Recurrent AML (age 60+) & $\begin{array}{l}\text { Voluntarily withdrawn in } 2010 \text {, due to } \\
\text { product safety issues and lack of clinical } \\
\text { benefit }\end{array}$ \\
\hline
\end{tabular}

\begin{tabular}{|c|c|c|c|c|c|}
\hline \multicolumn{6}{|l|}{ Adcetris } \\
\hline $\begin{array}{l}\text { Brentuximab } \\
\text { vedotin }\end{array}$ & Seattle Genetics & CD30 & $\begin{array}{l}\text { Mono-methyl } \\
\text { auristatin E } \\
\text { (MMAE) }\end{array}$ & 2011 & $\begin{array}{l}\text { Refractory Hodgkin's lymphoma } \\
\text { Refractory systemic anaplastic } \\
\text { large cell lymphoma }\end{array}$ \\
\hline
\end{tabular}

\begin{tabular}{|c|c|c|c|c|c|c|}
\hline \multicolumn{7}{|l|}{ Kadcyla } \\
\hline $\begin{array}{l}\text { Trastuzumab } \\
\text { emtansine }\end{array}$ & $\begin{array}{l}\text { Genentech/ } \\
\text { Roche }\end{array}$ & $\begin{array}{l}\text { Her2/ } \\
\text { neu }\end{array}$ & $\begin{array}{l}\text { Maytansinoid } \\
\text { DM1 }\end{array}$ & 2013 & $\begin{array}{l}\text { HER2-positive metastatic breast } \\
\text { cancer }\end{array}$ & 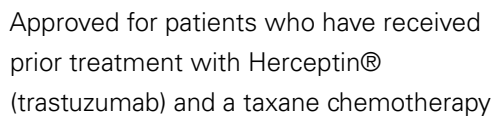 \\
\hline $\begin{array}{l}\text { Trade name } \\
\text { (generic) }\end{array}$ & Manufacturer & Target & Isotope & Approved & Indication & Comments \\
\hline \multicolumn{7}{|c|}{ RADIOIMMUNOTHERAPEUTICS (RITs) } \\
\hline $\begin{array}{l}\text { Zevalin } \\
\text { Ibritumomab } \\
\text { tiuxetan }\end{array}$ & $\begin{array}{l}\text { Biogen-Idec/ } \\
\text { Spectrum } \\
\text { pharmaceuticals }\end{array}$ & CD20 & $90 Y$ & 2002 & $\begin{array}{l}\text { Recurrent, low-grade or follicular } \\
\text { B-cell non-Hodgkin's lymphoma }\end{array}$ & \\
\hline \multicolumn{7}{|l|}{ Bexxar } \\
\hline $\begin{array}{l}\text { lodine (131I) } \\
\text { tositumomab }\end{array}$ & Corixa/GSK & CD20 & ${ }^{131} \mid$ & 2003 & $\begin{array}{l}\text { CD20 positive, follicular } \mathrm{NHL}, \\
\text { refractory to rituximab and } \\
\text { relapsed following chemotherapy }\end{array}$ & $\begin{array}{l}\text { Manufacture discontinued in } 2014 \text { due to } \\
\text { poor sales }\end{array}$ \\
\hline
\end{tabular}

support the potential use of this class for maximizing the therapeutic potential of targeted agents (27). As efforts continue across the industry to identify more disease-specific targets via a variety of genomic and proteomic discovery approaches (discussed below), more broadly expressed disease-associated targets and disease targeting agents have been identified from the screening of naturally occurring pathogenic proteins, intra-protein domains, and NPs scaffolds (29-31). These platforms offer the potential to employ theranostics: the co-development of a TCA along with the same targeting vector linked to a diagnostic agent to determine effective targeting and patient selection (32). Moreover, the use of TCA formats enables the potential repurposing of pharmacologically defined cytotoxic agents on the market, which may lead to faster development timelines of TCA by leveraging prior clinical experience, or the salvaging of compounds that showed anti-tumor activity in clinical trials but failed due to off-target toxicities. One should also bear in mind that, while the expression of the target is required, it may not be sufficient for long-lasting responses. In fact, due to the inherent heterogeneity of tumors and potential escape mechanisms [as seen for example with BRAF inhibitors (33)], theranostics and the TCA strategy in general would likely benefit from being combined with other drugs that have different mode of action and/or target.

\section{NANOPARTICLES AND APTAMERS}

Over the past two decades, the use of NPs has shown promise in delivering therapeutic drugs to malignant cells. Early NP-derived agents were primarily designed by optimizing particle size, chemical composition (lipids, silica, nucleic acids), and charge in an attempt to deliver tumor-specificity (34). Next generation NP technologies incorporated the use of disease-specific ligands, such as antibodies and aptamers, which could bind to disease-associated cell surface receptors and deliver therapeutic SCEs. Unfortunately, as mentioned above, the discovery of widely expressed diseasespecific receptors that can mediate robust internalization are infrequent. More recently, aptamer-bound NPs have been found to be useful in delivering cytotoxic agents to cancers by targeting diseasespecific epitopes on cell surface tumor antigens (35). Peptide aptamers are combinatorial protein molecules usually consisting of short peptides inserted within a scaffold protein resulting in conformational assortment that creates a target-binding diversity. Nucleic acid-based aptamers can achieve similar levels of conformational diversity and target specificity as peptide-based aptamers. Since nucleic acids are also being explored as NP to carry, deliver, and release chemotherapeutic agents, they may represent unique building blocks for both aptamers and NPs manufacturing. The use of aptamers expands the ability to identify subtle differences in the topographical structure of cell surface tumor 
antigen motifs that are not as easily recognized by traditional proteomic platforms. In light of their size, aptamer-guided NPs have been further engineered as theranostics, whereby the NP contains the targeting aptamer, a cytotoxic agent and an imaging agent that can monitor tumor uptake directly in the patient (36). Patients showing tumor-specific uptake are then deemed suitable for NP-cytotoxic therapy while those that do not can pursue other therapeutic options. Again, despite these promising results, challenges still remain in aptamer-guided NP theranostics including non-specific NP tissue binding, systemic stability, GMP manufacturing, and broad-based application to multiple cancer types. It is worth noting that the successful development of targeted NPs will be demonstrated through a combination of target specificity, a high tumor-to-normal tissue ratio and affinity that will enable the agent to "find and bind" low target expression to deliver their cytotoxic payload. Similarly, these properties are required for their use in diagnostic modalities including patient selection and monitoring of therapeutic efficacy. Table 5 contains a list of marketed and clinical stage NPs being developed for oncology.

\section{NATURAL AGENTS TARGETING TUMORS}

Several natural agents are able to target differentially expressed or conformation-specific cell surface antigens that are not easily identified by nucleic acid or proteomic analyses nor are easily targeted using traditional protein/antibody approaches. In particular, proteins, toxins or metabolites contained within plants, insects, arthropods, reptiles, viruses, and bacteria have yielded a number of agents capable of binding to specific host cell surface and intracellular proteins as a means to defend against predators and/or suppress their immune system as well as paralyze or even kill their prey $(37,38)$. Biochemical studies using natural agents from these sources have found them to have disparate activities. These include those that bind and are retained on the cell surface to suppress the activity of enzymes and channels while others have been shown to internalize upon binding to cell type-specific cell surface proteins to suppress intracellular functions. Naturally occurring polypeptides (NOP) from these sources include the following agents: vacuolating toxin $\mathrm{A}$ (VacA), which enters human cells via sphingomyelin (39); hepatitis $C$ viral coat protein, which enters cells via claudin-1 (40); Clostridium perfringens enterotoxin, which binds to claudin- 4 and causes cytotoxicity in cancer cells (41); crotamine, a toxin from rattlesnake venom that enters cells via heparin sulfate proteoglycans (42); and cholorotoxin, which binds to activated epithelial cells and internalizes via the annexin A2 complex $(43,44)$. Upon further experimental validation of tumor selectivity, any of these agents may serve as potential targeting moieties in the context of a TCA and could also be incorporated into theranostics platforms.

A critical factor for a therapeutic conjugate to provide clinical benefit is the ability to be systemically maintained at a certain molar level in order for the drug to effectively reach the target cells and accumulate at a concentration sufficient for the cytotoxin to exert its pharmacologic effect. Potential drawbacks of using NPs are their relative short serum and intracellular half-lives making extensive dosing and formulation studies critical for their success (45). Alternatively, NOPs have been selected by nature for their ability to impact cellular targets and maintain their function upon exposure. Moreover, their structures have evolved to withstand systemic degradation and immune responses by the host's serum proteolytic and host defense systems. These features along with

Table 5 | Examples of clinical stage nanoparticles and naturally occurring proteins in development for oncology.

\begin{tabular}{|c|c|c|c|c|}
\hline Organization & Compound name & Compound description & Target/active agent & Development stage \\
\hline Alnylam & ALN-VSP & Liposomal based nanoparticle containing siRNA & KSD and $V E G F /$ siRNA & Phase 1 \\
\hline \multicolumn{5}{|l|}{ Pharmaceuticals } \\
\hline BIND Biosciences & Bind-014 & $\begin{array}{l}\text { Polylactide-polyethylene glycol biopolymer nanoparticle } \\
\text { containing a chemotoxin and targeting ligand }\end{array}$ & PSMA/docetaxel & Phase 2 \\
\hline Celgene & Nab-paclitaxel & Albumin based nanoparticle & Paclitaxel & $\begin{array}{l}\text { Approved } \\
\text { (Abraxane®) }\end{array}$ \\
\hline Cerulean Pharma & CRLX-101 & $\begin{array}{l}\text { Cyclodextrin-based nanoparticle encapsulating a } \\
\text { chemotoxin }\end{array}$ & Camptothecin & Phase $1 / 2$ \\
\hline $\begin{array}{l}\text { Janssen } \\
\text { Pharmaceuticals }\end{array}$ & $\begin{array}{l}\text { Pegylated liposomal } \\
\text { doxorubicin }\end{array}$ & $\begin{array}{l}\text { Pegylated liposomal nanoparticle containing a } \\
\text { chemotoxin }\end{array}$ & Doxorubicin & Approved (Doxil@) \\
\hline Morphotek & TM601 & $\begin{array}{l}36 \text { Amino acid peptide from scorpion venom that binds } \\
\text { transformed cells and tumor endothelial cells via } \\
\text { annexin A2 complex }\end{array}$ & Annexin A2 complex & $\begin{array}{l}\text { Phase } 1 \text { (naked } \\
\text { peptide format) }\end{array}$ \\
\hline $\begin{array}{l}\text { University of } \\
\text { Illinois at Chicago }\end{array}$ & NSC745104 & $\begin{array}{l}28 \text { Amino acid fragment of the protein cupredoxin } \\
\text { azurin from pseudomonas aeruginosa that increases } \\
\text { intracellular p53 concentrations }\end{array}$ & p53 & Phase 1 \\
\hline
\end{tabular}

KSD, kinesin spindle protein; PSMA, prostate-specific membrane antigen; VEGF, vascular endothelial growth factor. 
their small molecular size warrant exploring NOP potential applications in theranostics platforms and large-scale manufacturing for development. Furthermore, NOPs could find applications in immunohistochemistry and potentially in biofluid-based assays for soluble ligands or in the detection of specific circulating tumor cells (CTCs).

Screening of natural peptides and cell penetrating peptides may offer an advantage for rapid development of targeted therapy by using cell-specific uptake as a predictive marker for therapeutic benefit. This approach may offer a more rapid approach for developing personalized medicines over traditional molecular association, pharmacogenomic, and/or gene signature platforms that may require longer timelines for discovery and validation. However, the use of the latter can be combined during development once biomarker signature profiles have been reproducibly validated for predictive responses to treatment for a disease or disease-specific targeting agent. Table 5 contains a list of some NOPs being developed for oncology.

\section{EXAMPLE OF NATURALLY OCCURRING POLYPEPTIDE: CHLOROTOXIN}

Chlorotoxin (CTX) is one of several NOPs that may be utilized for development of theranostics. Protein fractions of the venom from the Israeli scorpion, Leirius quinquestriatus were screened for the ability to selectively suppress tumor cell growth while leaving normal epithelial cells unaffected (46). This effort identified a 36 amino acid peptide (CTX) that is able to preferentially bind tumor vs. normal epithelial cells and perturb cell growth. Molecular studies have suggested that CTX binds and internalizes into a wide range of tumor types via the annexin A2 complex, a ubiquitously expressed intracellular protein in normal cells that is found expressed in complexes on the exterior surface of extracellular membranes of transformed cells (44). Preclinical studies have shown the ability of CTX to deliver radionuclides, complex dyes, as well as NPs preferentially to tumor cells in vitro and in vivo (47). In addition, preclinical studies have also shown CTX to have antiangiogenic activity as a naked peptide (48). Synthetic CTX has been tested in clinical trials and has shown the ability to deliver specifically conjugated ${ }^{131}$ I-radionuclide to tumors after local or systemic delivery with no detectable uptake observed in normal tissues (49) as well as affect angiogenesis as a naked peptide in a Phase 1 trial. The platform is currently being expanded for diagnostic applications (49) and for delivery of cytotoxic compounds including radionuclides to tumors (unpublished observations). The preclinical and clinical studies reported to date suggest a natural compound like CTX could be formatted as a theranostic agent to support personalized medicine. This would be beneficial in light of the broad presence of cell surface annexin A2 complexes in transformed vs. normal cells.

Several studies have provided examples of how CTX could potentially be used as a theranostic agent for cancer. These include imaging studies demonstrating CTX conjugate localization to tumors vs. normal tissues. In one format, CTX has been developed as an imaging bioconjugate composed of CTX and Cy5.5, a fluorescent agent that emits photons in the near-IR spectrum (49). The bioconjugate has been shown to be useful in detecting cancer foci and metastases non-invasively under surgical operating conditions. Systemically, a CTX radionuclide conjugate has been shown to detect metastatic lesions in cancer patients with peripheral and CNS disease (50). Ongoing efforts are aimed at selecting the payload(s) with theranostic features as well as optimizing conjugation chemistry for delivering both a cytotoxin and a tracer to the tumor site.

\section{THERANOSTICS CHALLENGES AND OPPORTUNITIES: USE OF CO-DEVELOPING DIAGNOSTIC AND THERAPEUTIC TARGETING VECTORS}

The definition of theranostics (the merging of the words therapeutics with diagnostics) can be very broad. In its most traditional sense of diagnostics-guided therapy, the concept of theranostics can be identified in the previously cited example, whereby glucose blood levels are measured to determine the timing of the treatment as well as which patients will benefit the most from a hormone (insulin)-based therapy. Nowadays, detecting BRAF mutation is equivalent to measuring blood glucose in that it allows identifying which cancer patients would benefit from an anti-cancer agent targeting a specific kinase (e.g., targeted theranostics against mutated BRAF). In both examples, the diagnostic tool and the therapeutic agent are completely different because they share no molecular components. On the other hand, these two examples differ at least in one regard: while glucose levels represent a "nontargeted" biomarker of the disease state (the true therapeutic target being insulin receptor), detection of BRAF mutation underpins the very presence of the target against which the targeted therapeutic agent has an inhibitory effect. The mutated BRAF constitutes both a therapeutic target as well as a disease biomarker. In another incarnation of targeted theranostics, the targeting agent could be employed in both the diagnostics and therapeutics strategy. In this instance, the diagnostic and the therapeutic agents do share at least one molecular component. Let us call it "leveraged theranostics." Hence, we can describe at least three different theranostics classes: non-targeted, targeted, and leveraged (Figure 1).

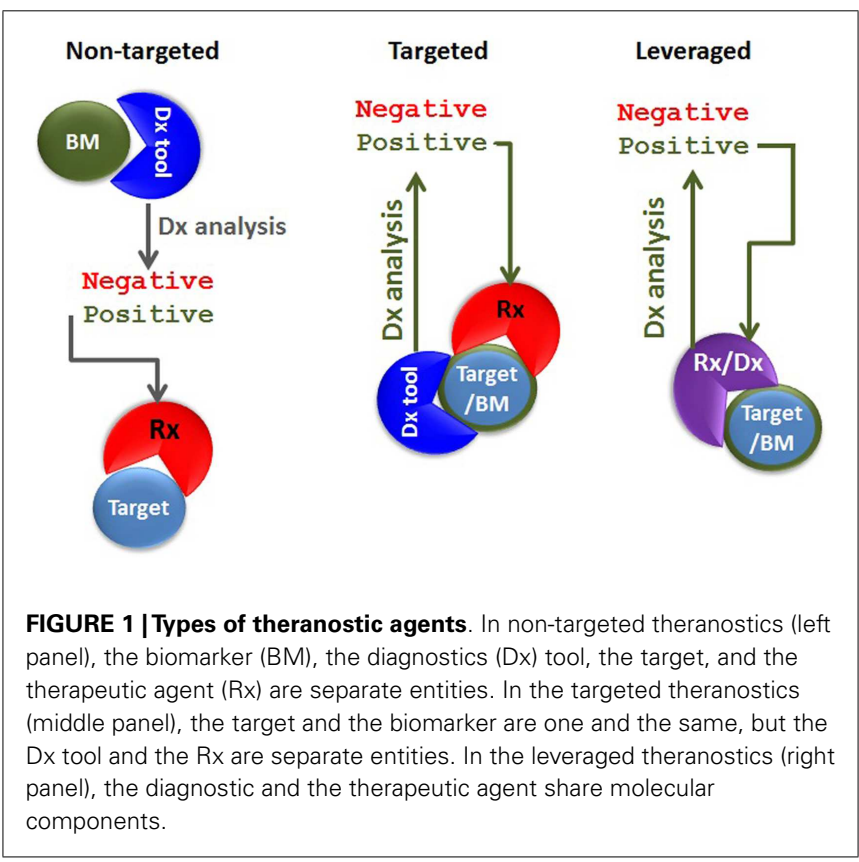


Monoclonal antibodies, antibody fragments, NPs, or NOPs may be armed with payloads and deployed in a leveraged theranostic strategy through the clever use of chemical linkers or couplers. One can envision three basic configurations for a leveraged theranostic compound: (1) one payload for therapy and one for diagnostics, with these payloads conjugated on different batches of the same targeting molecule; this configuration involves a single manufacturing process for the targeting moiety, and possibly one process for the linker attachment, but two separate processes for the conjugation of the two payload types; (2) one payload for therapy and one for diagnostics co-conjugated on the same targeting moiety; this implies a single compound and manufacturing process and represents a more ideal scenario; and finally (3) a single payload that can be cytotoxic as well as used for tumor uptake monitoring; this configuration allows for a single compound, manufacturing and conjugation process represents the most ideal scenario. An example of the first configuration (Figure 2A) is offered by the use of specific radionuclides. A radionuclide could be optimal for cytotoxicity but suboptimal for imaging, or vice versa. However, even by using currently available radionuclides, a single targeting agent such as CTX could be "functionalized" using a single chelator (hence a single manufacturing process for the targeting, functionalized moiety), and conjugated to Indium-111 for patient selection and Yttrium-90 for delivering cytotoxicity to the tumor by using two separate conjugation processes. Indium-111, while an excellent imaging agent, is not useful for therapy due to its low tissue penetration characteristic. These properties are reversed in Yttrium-90. Other radionucleotide pairs could be selected to satisfy the desired pharmacological as well as pharmacodynamic properties of the theranostic agent being pursued.

In the second configuration (Figure 2B), one where both payloads are co-attached on the same targeting molecule, one needs to be mindful of stereochemical interferences. For example, multiple payloads can disrupt the tumor cell binding activity of small targeting peptides such as CTX (36 amino acids). Structure-activity relationship analysis would need to be conducted to identify the best chemistry and attachment sites on both the targeting and payload molecules. NPs inherently offer the opportunity to carry multiple payloads to the tumor, including cytotoxins and diagnostic agents, but may not be sufficiently tumor-specific unless coupled with a targeting moiety. Another challenge using multiple payloads could be achieving a defined chemical homogeneity necessary for regulatory approval using a cost-effective manufacturing process.

The third configuration type (Figure 2C) has been achieved over the past several years by employing iodine-131, which, as noted above, suffers from the complexity of its handling. Therefore, this configuration could be improved by the selection of optimized radionuclides, their improved manufacturing processes, storage, and handling procedures, and by more sensitive whole-body radio-imaging devices. A new candidate for this mono-payload theranostic strategy is lutetium-177 (51). This radionuclide is a medium-energy $\beta$-emitter with a maximal tissue penetration of $2 \mathrm{~mm}$, hence capable of delivering its cytotoxic energy through several cell layers, while potentially having less off-target toxicity than yttrium-90 (12 mm penetration range). Lutetium-177 also emits low-energy $\gamma$-rays allowing both imaging

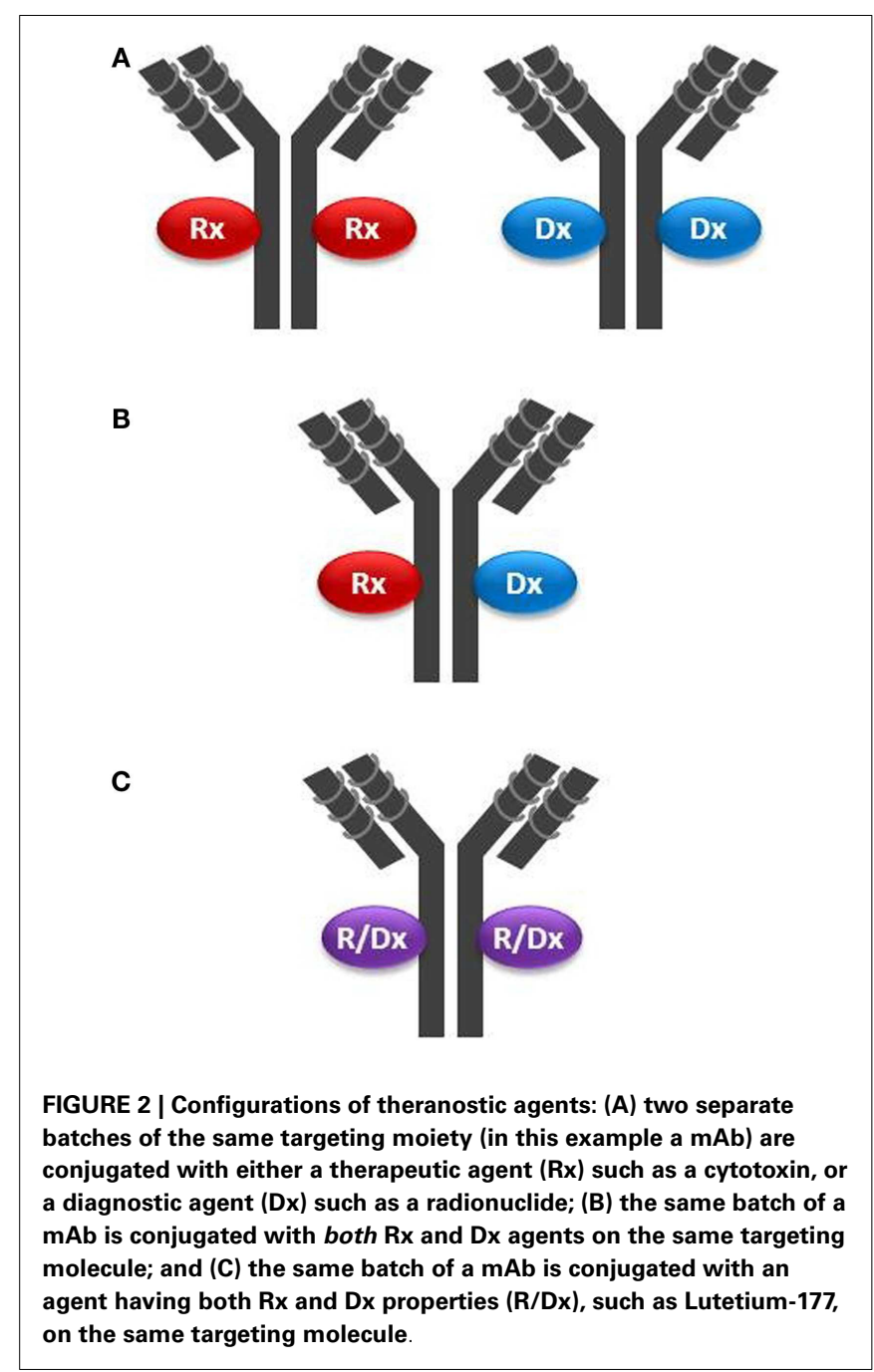

and dosimetry (quantitation of delivered or residual dose). Monopayload, radiolabeled compounds could be used theranostically, whereby: (i) low, diagnostic (non-therapeutic) doses are used for initial assessment of in vivo targeting; (ii) sub-therapeutic doses are administered for dosimetry, allowing precise dose selection, and for monitoring potential toxic effect; and (iii) higher, therapeutic doses are administered to continue to monitor toxicity in conjunction with tumor burden (efficacy, acquired resistance) and tumor uptake (disease modifications, such as loss of target). This strategy is already being implemented when using BEXXAR $^{\circledR}$, an iodine-131-labeled antibody targeting CD20 positive B-lymphoma cells. Using dosimetry, physicians can use a low dose $(5 \mathrm{mCi})$ and directly measure this TCA clearance rate. Patients with high tumor burden, splenomegaly, or bone marrow involvement tend to have faster clearance. Hence, the therapeutic dose (up to $90 \mathrm{mCi}$ ) can be prospectively individualized by using an equation (52).

By allowing patient selection and efficacy as well as toxicity monitoring, the potential success of pivotal trials using these theranostic strategies will allow the technological advancement and clinical benefit improvement of personalized medicine. Table 6 
Table 6 | Clinical stage theranostics.

\begin{tabular}{|c|c|c|c|c|c|c|}
\hline Organization & Rx compound & Dx compound & Targeting moiety & Target & $\begin{array}{l}\text { Configuration } \\
\text { type }\end{array}$ & $\begin{array}{l}\text { Development } \\
\text { stage }\end{array}$ \\
\hline Endocyte & Vinca alkaloid & Technetium-99m & Folate & Folate receptors & Figure 2A & Phase 3 \\
\hline Morphotek & lodine-131 & lodine-131 & Chlorotoxin & Annexin A2 & Figure 2C & Phase 2 \\
\hline GlaxoSmithKline & lodine-131 & lodine-131 & $\begin{array}{l}\text { Tositumomab (murine } \\
\text { lgG2a) }\end{array}$ & CD20 & Figure 2C & $\begin{array}{l}\text { Approved } \\
\text { (Bexxar®) }\end{array}$ \\
\hline Institut Jules Bordet & Lutetium-177 & Gallium-68 & $\begin{array}{l}\text { Octreotide } \\
\text { (somatostatin analog) }\end{array}$ & $\begin{array}{l}\text { Somatostatin } \\
\text { receptor }\end{array}$ & Figure 2A & Phase 2 \\
\hline Peregrine & Neutralizing mAb & F(ab')2-indium-124 & Bavituximab & Phosphatidylserine & Figure $2 \mathrm{~A}^{\mathrm{a}}$ & Phase $1^{b} /$ Phase $3^{c}$ \\
\hline $\begin{array}{l}\text { Memorial Sloan-Kettering } \\
\text { Cancer Center }\end{array}$ & lodine-131 & indium-124 & $8 \mathrm{H9}$ (murine lgG1) & B7-H3 & Figure 2A & Phase 1 \\
\hline $\begin{array}{l}\text { University Medical } \\
\text { Centre Groningen }\end{array}$ & Neutralizing mAb & Zirconium-89 & Trastuzumab & HER2 & Figure $2 \mathrm{~A}^{\mathrm{a}}$ & Phase 1/2 \\
\hline $\begin{array}{l}\text { Institut Jules } \\
\text { Bordet/Roche }\end{array}$ & Maytansine & Zirconium-89 & Trastuzumab & HER2 & Figure 2A & Phase 2 \\
\hline Areva Med LLC & Lead-212 & Lead-212 & Trastuzumab & HER2 & Figure 2C & Phase 1 \\
\hline
\end{tabular}

contains a list of clinical stage theranostics being developed for oncology.

\section{CONCLUSION AND FUTURE DIRECTIONS}

The use of personalized medicine has many attributes that make the practice invaluable to patients, the pharmaceutical industry, and the healthcare system. The ability to predefine patients with a high likelihood to respond to a given therapy will provide benefit to all parties. For patients, the ability to predict response will improve therapeutic outcome while avoiding unnecessary treatment with ineffective, potentially toxic drugs and thereby lead to a better quality of life, if not a cure. For the pharmaceutical industry, predictive biomarkers (i.e., informative $\mathrm{CDx}$ ) may improve the probability of success that a drug will provide meaningful clinical results in trials leading to higher approval rates by regulatory authorities and value-creation for the industry and patients alike. For the healthcare system, the ability to avoid futile, potentially toxic therapies will reduce not only drug costs but overall healthcare costs and potentially improve patient health by identifying agents that have a higher probability of success in treating their specific disease. While these attributes are compelling, the ability to implement platforms to support personalized medicine remains challenging. Attempts to identify disease-specific targets or molecular signatures that can provide predictive response outcomes are ongoing across the pharmaceutical industry and academia alike for many indications. While a few successful examples have been achieved, the majority of development programs are handicapped by the paucity of targets associated with disease as well as the time and effort required to validate molecular signatures that can unequivocally and reproducibly predict patient response to non-targeted SCEs.

As the industry refines its technologies and methods to improve upon personalized medicine, a few platforms exist today that may support this initiative in real-time clinical trials. Of particular note is the use of NPs and NOPs that can be conjugated to a therapeutic agent to improve disease-specific uptake of cytotoxic agents and patient response. As discussed above, the use of theranostic strategies employing, for example, a TCA and its co-developed diagnostic vector for in vivo prescreening of patients for tumorspecific uptake, offers the opportunity to identify patients with the highest likelihood of benefiting from the TCA therapy. Realtime theranostic imaging strategies may offer an alternative or supplemental approach to the more time consuming pharmacogenomics and/or molecular marker signature analyses for predicting response, although these approaches may yet prove complementary rather than mutually exclusive. Moreover, the application of NP or NOP containing vectors that enable their use for therapy in a broader range and higher frequency of cancers may offer better options than antibody-based therapies whose target is likely restricted to a few indications or across several indications at a low frequency. Other targeting agents in addition to NP and NOPs have also been formatted to support theranostic therapies. Studies in several cancers have found that cell surface proteins such as the folate receptor alpha (FOLR1), a highly expressed protein on ovarian and other epithelial derived cancers can be exploited in a theranostic context (53-55). Strategies to develop conjugates 
that can be selectively taken up via FOLR1 have been pursued in clinical trials whereby results from these studies have shown that patients whose tumors with uptake of an imaging-folate diagnostic conjugate have enhanced clinical response to a folate-vinblastine therapeutic conjugate compared to patients who do not have folate diagnostic vector uptake (56). Similar approaches to develop conjugate-imaging/conjugate-therapeutic vector pairs have suggested improved patient selection and therapeutic responses. Other examples of diagnostic and therapeutic targeting vector pairs have employed NP technologies to co-develop complexes containing diagnostic agents and an anti-cancer agent, including siRNAs (57). In all cases, the use of TCA and a co-developed targeting diagnostic vector offer alternative methods for delivering personalized therapies to patients in need of new treatments. The key, therefore, for the successful and continued evolution toward personalized medicine is co-development of both the therapeutic and the diagnostic agents as well as diagnostic modalities beginning at the time of target discovery and preclinical studies and continuing through clinical validation and regulatory approvals.

\section{REFERENCES}

1. Woodcock J. Assessing the clinical utility of diagnostics used in drug therapy. Clin Pharmacol Ther (2010) 88:765-773. doi:10.1038/clpt.2010.230

2. Nicolaides NC, Sass PM, Grasso L. Advances in targeted therapeutic agents. Expert Opin Drug Discov (2010) 5:1123-40. doi:10.1517/17460441.2010.521496

3. Eifert C, Powers RS. From cancer genomes to oncogenic drivers, tumour dependencies and therapeutic targets. Nat Rev Cancer (2012) 12:572-8. doi:10.1038/ $\operatorname{nrc} 3299$

4. Druker BJ, Guilhot F, O’Brien SG, Gathmann I, Kantarjian H, Gattermann N, et al. Five-year follow-up of patients receiving imatinib for chronic myeloid leukemia. N Engl J Med (2006) 355:2408-17. doi:10.1056/NEJMoa062867

5. Mologni L. Inhibitors of the anaplastic lymphoma kinase. Expert Opin Investig Drugs (2012) 21:985-94. doi:10.1517/13543784.2012.690031

6. Chapman PB, Hauschild A, Robert C, Haanen JB, Ascierto P, Larkin J, et al. Improved survival with vemurafenib in melanoma with BRAF V600E mutation. N Engl J Med (2011) 364:2507-16. doi:10.1056/NEJMoa1103782

7. Towse A, Ossa D, Veenstra D, Carlson J, Garrison L. Understanding the economic value of molecular diagnostic tests: case studies and lessons learned. J Pers Med (2013) 3:288-305. doi:10.3390/jpm3040288

8. van't Veer LJ, Dai H, van de Vijver MJ, He YD, Hart AA, Hart AA, et al. Gene expression profiling predicts clinical outcome of breast cancer. Nature (2002) 415:530-6. doi:10.1038/415530a

9. National Comprehensive Cancer Network. Guidelines for Patients. Available from: http://www.nccn.org/patients/guidelines/cancers.aspx\#breast

10. Paik S, Tang G, Shak S, Kim C, Baker J, Kim W, et al. Gene expression and benefit of chemotherapy in women with node-negative, estrogen receptor-positive breast cancer. J Clin Oncol (2006) 24:3726-34. doi:10.1200/JCO.2005.04.7985

11. Park YY, Lee SS, Lim JY, Kim SC, Kim SB, Sohn BH, et al. Comparison of prognostic genomic predictors in colorectal cancer. PLoS One (2013) 8:e60778. doi:10.1371/journal.pone.0060778

12. O'Shaughnessy J, Osborne C, Pippen J, Yoffe M, Patt D, Monoghan G, et al. Efficacy of BSI-201, a poly (ADP-ribose) polymerase-1 (PARP1) inhibitor, in combination with gemcitabine/carboplatin $(\mathrm{G} / \mathrm{C})$ in patients with metastatic triple-negative breast cancer (TNBC): results of a randomized phase II trial. J Clin Oncol (2009) 27:18s.

13. Trail PA, Willner D, Lasch SJ, Henderson AJ, Hofstead S, Casazza AM, et al. Cure of xenografted human carcinomas by BR96-doxorubicin immunoconjugates. Science (1993) 261:212-5. doi:10.1126/science.8327892

14. Junutula JR, Raab H, Clark S, Bhakta S, Leipold DD, Weir S, et al. Site-specific conjugation of a cytotoxic drug to an antibody improves the therapeutic index. Nat Biotechnol (2008) 26:925-32. doi:10.1038/nbt.1480

15. Witzig TE, Gordon LI, Cabanillas F, Czuczman MS, Emmanouilides C, Joyce R, et al. Randomized controlled trial of yttrium-90-labeled ibritumomab tiuxetan radioimmunotherapy versus rituximab immunotherapy for patients with relapsed or refractory low-grade, follicular, or transformed B-cell non-Hodgkin's lymphoma. J Clin Oncol (2002) 20:2453-63. doi:10.1200/JCO.2002.11.017

16. Kaminski MS, Zelenetz AD, Press OW, Saleh M, Leonard J, Fehrenbacher L, et al. Pivotal study of iodine I 131 tositumomab for chemotherapy-refractory lowgrade or transformed low-grade B-cell non-Hodgkin's lymphomas. J Clin Oncol (2001) 19:3918-28.

17. Burris HA, Rugo HS, Vukelja SJ, Vogel CL, Borson RA, Limentani S, et al. Phase II study of the antibody drug conjugate trastuzumab-DM1 for the treatment of human epidermal growth factor receptor 2 (HER2)-positive breast cancer after prior HER2-directed therapy. J Clin Oncol (2011) 29:398-405. doi:10.1200/JCO.2010.29.5865

18. Foyil KV, Bartlett NL. Brentuximab vedotin for the treatment of CD30+ lymphomas. Immunotherapy (2011) 3:475-85. doi:10.2217/imt.11.15

19. Trail PA. Antibody drug conjugates as cancer therapeutics. Antibodies (2013) 2:113-29. doi:10.3390/antib2010113

20. Abbas N, Heyerdahl H, Bruland OS, Borrebæk J, Nesland J, Dahle J. Experimental $\alpha$-particle radioimmunotherapy of breast cancer using 227Th-labeled p-benzyl-DOTA-trastuzumab. EJNMMI Res (2011) 1:1-12. doi:10.1186/2191219X-1-18

21. Adams GP, Schier R, McCall AM, Simmons HH, Horak EM, Alpaugh RK, et al. High affinity restricts the localization and tumor penetration of single-chain $\mathrm{Fv}$ antibody molecules. Cancer Res (2001) 61:4750-5.

22. Burrell RA, McGranahan N, Bartek J, Swanton C. The causes and consequences of genetic heterogeneity in cancer evolution. Nature (2013) 501:338-45. doi:10.1038/nature12625

23. FDA Press Release. FDA Allows Marketing of Four "Next Generation" Gene Sequencing devices: Two Devices Aid in Screening and Diagnosis of Cystic Fibrosis (2013). Available from: http://www.fda.gov/newsevents/newsroom/ pressannouncements/ucm $375742 . h t m l$

24. Holliger P, Winter G. Diabodies: small bispecific antibody fragments. Cancer Immunol Immunother (1997) 45:128-30. doi:10.1007/s002620050414

25. Jain M, Chauhan SC, Singh AP, Venkatraman G, Colcher D, Batra SK. Penetratin improves tumor retention of single-chain antibodies: a novel step toward optimization of radioimmunotherapy of solid tumors. Cancer Res (2005) 65:7840-6.

26. Batra SK, Jain M, Wittel UA, Chauhan SC, Colcher D. Pharmacokinetics and biodistribution of genetically engineered antibodies. Curr Opin Biotechnol (2002) 13:603-8. doi:10.1016/S0958-1669(02)00352-X

27. Kavak E, Ünlü M, Nistér M, Koman A. Meta-analysis of cancer gene expression signatures reveals new cancer genes, SAGE tags and tumor associated regions of co-regulation. Nucleic Acids Res (2010) 20:7008-21. doi:10.1093/nar/gkq574

28. Cottu PH, Asselah J, Lae M, Pierga JY, Diéras V, Mignot L, et al. Intratumoral heterogeneity of HER2/neu expression and its consequences for the management of advanced breast cancer. Ann Oncol (2008) 19:595-7. doi:10.1093/annonc/ mdn021

29. Olivera BM, Rivier J, Clark C, Ramilo CA, Corpuz GP, Ramilo CA, et al. Diversity of Conus neuropeptides. Science (1990) 249:257-63. doi:10.1126/science. 2165278

30. Snyder EL, Dowdy SF. Recent advances in the use of protein transduction domains for the delivery of peptides, proteins and nucleic acids in vivo. Expert Opin Drug Deliv (2005) 2:43-51. doi:10.1517/17425247.2.1.43

31. Petros RA, DeSimone JM. Strategies in the design of nanoparticles for therapeutic applications. Nat. Rev. Drug Discov (2010) 9:615-27. doi:10.1038/nrd2591

32. Ozdemir V, Williams-Jones B, Glatt SJ, Tsuang MT, Lohr JB, Reist C. Shifting emphasis from pharmacogenomics to theragnostics. Nat Biotechnol (2006) 24:942-6. doi:10.1038/nbt0806-942

33. Wagle N, Emery C, Berger MF, Davis MJ, Sawyer A, Pochanard P, et al. Dissecting therapeutic resistance to RAF inhibition in melanoma by tumor genomic profiling. J Clin Oncol (2011) 29:3085-96. doi:10.1200/JCO.2010.33.2312

34. Kim JK, Choi KJ, Lee M, Jo MH, Kim S. Aptamer theragnostic. Biomaterials (2012) 33:207-17. doi:10.1016/j.biomaterials.2011.09.023

35. Farokhzad OC, Jon S, Khademhosseini A, Tran TN, Lavan DA, Langer R. Nanoparticle aptamer bioconjugates: a new approach for targeting prostate cancer cells. Cancer Res (2004) 64:7668-72. doi:10.1158/0008-5472.CAN-042550

36. Bates PJ, Laber DA, Miller DM, Thomas SD, Trent JO. Discovery and development of the G-rich oligonucleotide AS1411 as a novel treatment for cancer. Exp Mol Pathol (2009) 86:151-64. doi:10.1016/j.yexmp.2009.01.004 
37. De Luca V, Salim V, Atsumi SM, Yu F. Mining the biodiversity of plants: a revolution in the making. Science (2012) 336:1658-61. doi:10.1126/science.1217410

38. Escoubas P, King GF. Venomics as a drug discovery platform. Expert Rev Proteomics (2009) 6(221-224):2009. doi:10.1586/epr.09.45

39. Gupta VR, Wilson BA, Blanke SR. Sphingomyelin is important for the cellular entry and intracellular localization of Helicobacter pylori. Cell Microbiol (2010) 12:1517-33. doi:10.1111/j.1462-5822.2010.01487.x

40. Evans MJ, von Hahn T, Tscherne DM, Syder AJ, Panis M, Wölk B, et al. Claudin-1 is a hepatitis C virus co-receptor required for a late step in entry. Nature (2007) 446:801-5. doi:10.1038/nature05654

41. Michl P, Buchholz M, Rolke M, Kunsch S, Löhr M, McClane B, et al. Claudin4: a new target for pancreatic cancer treatment using Clostridium perfringens enterotoxin. Gastroenterology (2001) 121:678-84. doi:10.1053/gast.2001.27124

42. Nascimento FD, Hayashi MAF, Kerkis A, Oliveira V, Oliveira EB, RádisBaptista G, et al. Crotamine mediates gene delivery into cells through the binding to heparan sulfate proteoglycans. J Biol Chem (2007) 282:21349-60. doi:10.1074/jbc.M604876200

43. DeBin JA, Maggio JE, Strichartz GR. Purification and characterization of chlorotoxin, a chloride channel ligand from the venom of the scorpion. Am J Physiol (1993) 264:C361-9.

44. Kesavan K, Ratliff J, Johnson EW, Dahlberg W, Asara JM, Misra P, et al. Annexin A2 is a molecular target for TM601, a peptide with tumor-targeting and antiangiogenic effects. J Biol Chem (2010) 285:4366-74. doi:10.1074/jbc.M109. 066092

45. Neuberger T, Schöpf B, Hofmann H, Hofmann M, von Rechenberg B. Superparamagnetic nanoparticles for biomedical applications: possibilities and limitations of a new drug delivery system. J Magn Magn Mater (2005) 293:483-96. doi:10.1016/j.jmmm.2005.01.064

46. Lyons SA, O’Neal J, Sontheimer H. Chlorotoxin, a scorpion-derived peptide, specifically binds to gliomas and tumors of neuroectodermal origin. Glia (2002) 39:162-73. doi:10.1002/glia.10083

47. Kievit FM, Veiseh O, Fang C, Bhattarai N, Lee D, Ellenbogen RD, et al. Chlorotoxin labeled magnetic nanovectors for targeted gene delivery to glioma. J Drug Tar (2012) 20:67-75. doi:10.1021/nn1008512

48. Lima e Silva R, Shen J, Gong YY, Seidel CP, Hackett SF, Kesavan K, et al. Agents that bind annexin A2 suppress ocular neovascularization. J Cell Physiol (2010) 225:855-64. doi:10.1002/jcp.22296

49. Mamelak AN, Jacoby DB. Targeted delivery of antitumoral therapy to glioma and other malignancies with synthetic chlorotoxin (TM-601). Expert Opin Drug Deliv (2007) 4:175-86. doi:10.1517/17425247.4.2.175

50. Veiseh M, Gabikian P, Bahrami SB, Veiseh O, Zhang M, Hackman RC, et al. Tumor paint: a chlorotoxin:Cy5.5 bioconjugate for intraoperative visualization of cancer foci. Cancer Res (2007) 67:6882-8. doi:10.1158/0008-5472.CAN-063948

51. Gribbin TE, Senzer N, Raizer JJ, Shen S, Nabors LB, Wiranowska M, et al. A phase I evaluation of intravenous (IV) 131I-chlorotoxin delivery to solid peripheral and intracranial tumors. J Clin Oncol (2009) 27:e14507.

52. Kam BL, Teunissen JJ, Krenning EP, de Herder WW, Khan S, van Vliet EI, et al. Lutetium-labelled peptides for therapy of neuroendocrine tumours. Eur J Nucl Med Mol Imaging (2012) 39:S103-12. doi:10.1007/s00259-011-2039-y

53. Seldin DW. Techniques for using BEXXAR for the treatment of non-Hodgkin's lymphoma. J Nucl Med Technol (2002) 30:109-14.

54. Ebel W, Routhier EL, Foley B, Jacob S, McDonough JM, Patel RK, et al. Preclinical evaluation of MORAb-003, a humanized monoclonal antibody antagonizing folate receptor-alpha. Cancer Immun (2007) 7:6-14.

55. O'Shannessy DJ, Somers EB, Albone E, Cheng X, Park YC, Tomkowicz BE, et al. Characterization of the human folate receptor alpha via novel antibody-based probes. Oncotarget (2011) 2:1227-43.

56. Naumann RW, Coleman RL, Burger RA, Sausville EA, Kutarska E, et al. PRECEDENT: a randomized phase II trial comparing vintafolide (EC145) and pegylated liposomal doxorubicin (PLD) in combination versus PLD alone in patients with platinum-resistant ovarian cancer. J Clin Oncol (2013) 31:4400-6. doi:10.1200/JCO.2013.49.7685

57. Medarova Z, Pham W, Farrar C, Petkova V, Moore A. In vivo imaging of siRNA delivery and silencing in tumors. Nat Med (2007) 13:372-7. doi:10.1038/ $\mathrm{nm} 1486$

Conflict of Interest Statement: The authors declare that the research was conducted in the absence of any commercial or financial relationships that could be construed as a potential conflict of interest.

Received: 01 April 2014; accepted: 24 May 2014; published online: 13 June 2014. Citation: Nicolaides NC, O'Shannessy DJ, Albone E and Grasso L (2014) Codevelopment of diagnostic vectors to support targeted therapies and theranostics: essential tools in personalized cancer therapy. Front. Oncol. 4:141. doi: 10.3389/fonc.2014.00141

This article was submitted to Pharmacology of Anti-Cancer Drugs, a section of the journal Frontiers in Oncology.

Copyright $(2) 2014$ Nicolaides, O'Shannessy, Albone and Grasso. This is an open-access article distributed under the terms of the Creative Commons Attribution License (CC BY). The use, distribution or reproduction in other forums is permitted, provided the original author(s) or licensor are credited and that the original publication in this journal is cited, in accordance with accepted academic practice. No use, distribution or reproduction is permitted which does not comply with these terms. 